\title{
Community Empowerment Based on the Local Wisdom (A Comparative Study in Kampung Ternak Yogyakarta and Jambu Getas Merah Kendal, Central Java, Indonesia)
}

\author{
Raharjati Arbuningtiyas ${ }^{1}$, Lukman Hakim ${ }^{2, *}$ \\ 1 Sharia Economic Student, Universitas Muhammadiyah Yogyakarta, Indonesia \\ 2 Graduate Student of Communication Studies, Universitas Gadjah Mada, Indonesia \\ *e-mail: lukmanelhakim681@gmail.com
}

\begin{abstract}
This study aims to find out the mechanism and empowerment pattern of community empowerment through Kampung Ternak Program and Jambu Getas Merah Community located in Yogyakarta and Kendal, Central Java Indonesia. It also aims to compare two different programs in its location. Then, it shows the effect of empowerment activities on the members of this program as well as to figure out the enabling and inhibiting factors in conducting this program in the field. This study was a field study with a qualitative approach and used descriptive analysis approach method. Observation, interview and documentation study were the data gathering techniques used in this study, and then the data were interpreted according to the phenomena and issues found in the field during research. The subjects of the study were selected by purposive sampling method. The result of the study shows that First, Kampung Ternak program and Jambu Biji Getas Merah have a different way to enlarge their product. Kampung Ternak helped by Dompet Dhuafa Yogyakarta, one of a non-profit organization for global empowerment. While Jambu Biji Getas Merah has created their own way to manage their activities. Second, the effect of this program is that there is increasing business profit, increasing the family living standard and improving skills and knowledge.
\end{abstract}

\section{Keywords}

Jambu Biji Getas Merah, Community Empowerment, Kampung Ternak, Local Wisdom.

Citation: Arbuningtyas. $\mathrm{R} \&$ Hakim. L: Community Enpowerment Based on the Local Wisdom (A Comparative Study in Kampung Ternak Yogyakarta and Jambu Getas Merah Kendal, Central Java, Indonesia) Proceeding of The American Studies International Conference 2018, Vol. 2. pp. 99-105. UGM Digital Press Social Sciences and Humanities, Yogyakarta (2019).

Published: May, 2019

\section{Introduction}

The survey of BPS (The Central Bureau of Statistics) shows that the number of poor people in Indonesia in March 2017 reached 10.64\% or equaled to 27.77 million people. This indicates a high level of poverty in Indonesia. A large number of poor people in this country requires a spirit of mutual and good cooperation from all parties to solve it. With a limited amount of resources both physically and financially, it is undeniable that the government has opened up many opportunities 
for various non-Governmental Organizations (NGOs) to contribute to alleviating poverty in Indonesia.

The community empowerment movement or also known as the philanthropic movement focuses on the issue of social development and community empowerment. This movement seems to be a response from the realization of pro-people development that is still not maximally conducted by the government. The philanthropic movement carried out by the government, both through the Ministry of Social Affairs and others is still manifested in the temporary social development activities or programs (Abidi, 2012, p. 198).

The researchers identified that this philanthropic movement is able to give positive effects to community development, especially in remote areas far from the city with limited access. They are poor not only materially but also demographically. Related to a Muslim-majority population in Indonesia, the development of Islamic philanthropy grows very rapidly. This phenomenon is marked by the growth of amil zakat organizations and institutions in many regions in Indonesia. According to FOZNAS (National Zakat Forum), there are more than 400 institutions joining the Zakat Forum until 2017. Based on the data of the National Zakat Forum (FOZNAS), it turns out that the zakat funds collected in 2017 amounted to 246 billion rupiahs and the total alms funds amounted to 143 billion rupiahs. With the potential zakat funds, all parties are required to develop them well, professionally, and responsibly.

Zakat to the mustahiq can help to improve the economic level if developed in productive fields. A mature concept such as the planning process and the implementation accuracy in compiling the causes and effects of the people's economic level is a characteristic of productive zakat. The effort to alleviate poverty through productive zakat is not only merely the responsibility of the government, but also the responsibility of the people, Islamic organizations, and non-governmental organizations. These organizations have a goal to optimize local initiatives and resources out of the government structure (Sartika, 2008, p. 77).

Furthermore, the interest in the community empowerment phenomenon carried out by zakat institutions and other non-governmental organizations (NGOs) led this research to examine how this movement works. The successful zakat institutions or NGOs in building communities always put forward the sustainability principle in every program development, especially in an economic program to manifest empowerment. They also work from the bottom up to see the existing potential in the region.

The focus of this research is two community empowerment programs in two different places. The first is the Livestock Village program of Dompet Dhuafa Yogyakarta. The uniqueness of the Livestock Village program is its management system. Dompet Dhuafa Yogyakarta built this program by involving the community through a social rowdy system. The profit-sharing system is also not like most of the existing rowdy ways in the community. Nearly one hundred percent belongs to the people, by the people, and for the people. The second is Kendal Red Getas Guava Cluster. This group originated from the community developing this product to be the flagship product of Kendal district.

Based on the research problems, this research aimed to study and compare the community empowerment programs in the two regions. The researchers wanted to explore the pattern and mechanism of empowerment programs in Kendal and Yogyakarta and the impact of the program. This research also examined the inhibiting and supporting factors of the community empowerment programs.

The results of this study were expected to contribute to the increase of the knowledge and the insight of community empowerment and could be used as a reference for further research. This research could be utilized as input and means of information for Dompet Dhuafa Yogyakarta and other similar institutions in improving the livestock village program and determining other policies to create the expected results.

\section{Theoretical Framework}

\subsection{The Economic Empowerment Concept}

Literally, the word "empowerment" comes from the word root "power". Empowerment (Suharto, 2014, p. 58) leads the weak groups to have the ability to meet their basic needs and to reach productive resources, so they can increase their income and participate in development and decisions affecting to them. Then, according to Darwan and Nur Iman (2009, p. 30), empowerment is a tool to show the achieved goals by the social change, namely empowered people with the knowledge, power, and ability to meet the physical, economic, and social needs. 
According to Sennet and Conat, helplessness, as the contrary of empowerment, is caused by many factors such as; the absence of economic security, the lack of experience in politics, the lack of information, the limited financial source, and the strong emotional and physical tension. Learner and Seeman believe that social inequality in the society is caused by an internalization process in the community making them weak because they consider themselves weak and powerless. Seeman refers to this situation to "alienation". The community empowerment is carried out with the aim of achieving the social conditions in which socio-cultural, political, economic, and technological transformations can be carried out by the community in a sustainable manner.

There a re three general characteristics of the community empowerment program (Wayan Edi, 2016, p. 241), namely:

1. Community base, the community as the main actor (subject) in planning and implementing the program.

2. Local resources-base, the creation of activities in accordance with the existing potential resources (natural and human).

3. Sustainable, a program serving as the initial motor of the sustainable development

\section{Results and Discussion}

\subsection{Empowerment Mechanism and Pattern of Livestock Village of Dompet Dhuafa Yogyakarta}

Dompet Dhuafa Yogyakarta's principle in zakat fund management is management by the process, not by the result, which emphasizes the structuring of the process rather than the results of the process. By conducting a good process, the infrastructure can be used properly. The Livestock Village program has started since 2013 in Sentolo. However, the 2013 and 2014 schemes are different. According to Nuryanto, the head of the Dhuafa Economic Program Division Yogyakarta, in 2013 Dompet Dhuafa program was still pragmatic; they conducted a livestock village program with a fattening scheme. The Livestock Village program with the fattening scheme was created due to the yearly need of the goats as the sacrificial animal on Eid Al-Adha or sacrificial animal stocking.

In addition to the need for sacrificial animal stocking, Dompet Dhuafa Yogyakarta also considered a faster income or cash flow. This fattening system needs shorter time in getting the result with a threemonth grace period and the stock farmer could sell the fattened goats. However, over time the government wants to increase the animal population to achieve meat self-sufficiency. Finally, in 2014 this fattening system was replaced by the breeding system.

In determining the program, Dompet Dhuafa Yogyakarta did it selectively. The conducted empowerment patterns or schemes must fulfill the rules or foundation of the program. There are four foundations or rules carried out by Dompet Dhuafa Yogyakarta, namely possessing sharia legal status, growing and developing, sustainable, and unique. After the program met these four rules, the program mechanism was carried out. The following stages are the Livestock Village empowerment program mechanism: 1) The determination of the location or target of the Livestock Village program, 2) The socialization of the program 3) The implementation of the Livestock Village program, 4) The assistance.

The requirements of the beneficiaries in this program are the willingness to be voluntary beneficiaries without any coercion from any party, the willingness to be assisted, the infrastructure possession to raise the animals, the feeding availability, and the productive age priority. The requirements are a must so that the empowerment works as well as possible. According to the Dompet Dhuafa Yogyakarta, the assistance is compulsory in the empowerment

The empowerment pattern used in this Livestock Village program is a social rowdy system. The rowdy scheme is much developed or used in the community, especially in rural communities. "Gaduh" according to Kamus Besar Bahasa Indonesia is a profit-sharing system in agriculture or animal husbandry (usually half or one-third of the business result. ("gaduh", (2019) in kbbi.web.id/gaduh) The rowdy scheme proclaimed by Dompet Dhuafa Yogyakarta is different from the rowdy scheme in general. The biggest profit sharing is gained by the stock farmers in the hope that they can later have their own livestock. Finally, the profit-sharing portion is $90: 10$, of which $90 \%$ for the stock farmer and $10 \%$ for the group treasury.

The illustration is as follows, a goatling can be separated from its broodstock and the group values it at four hundred thousand rupiahs (IDR 400,000), the stock farmer must pay $10 \%$ of four hundred thousand 
rupiahs (IDR 400,000) which equals to forty thousand rupiahs (IDR 40,000) to the group as the group treasury. This group treasury can be used by the groups to provide the broodstock for the new members of this group or other groups.

Then the next step by Dompet Dhuafa Yogyakarta is strengthening the human resources (HR) with the mentoring process by the facilitators. They are tasked with the supervising and monitoring the Livestock Village program development and strengthening the groups. Dompet Dhuafa together with the facilitators collaborates with several stakeholders such as the Department of Animal Husbandry and Faculty of Animal Husbandry UGM to provide the counseling on proper methods to raise the livestock, such as the appropriate stall making techniques, the manure making, and the feed fermentation techniques.

In order to achieve the objectives of the productive zakat of Dompet Dhuafa Yogyakarta, the continuous assistance is carried out for the stock farmers in the two hamlets. This assistance includes 1) the formation of stock farmer association. In Plengan Hamlet, Nadawazis Community consists of 15 households, and in Gunungbutak Hamlet, Ngudi Rejeki Community consists of 79 households. 2) holding the monthly meetings. 3) the construction of a decent goat stall. 4) the proportional feeding, 5) the feed fermentation training, 6) the comparative study to other farms, and 7) inviting the experts during the counseling.

\subsection{Empowerment Mechanism and Pattern of Kendal Red Getas Guava Cluster}

The beginning of the development of the Red Getas Guava Cluster (JASMER) originated from the failure of the farmers in cultivating their land. The land in Kendal is a rainfed rice field without good irrigation channels. The farmers initially planted their land with rice and Ambonese bananas. However, the results they harvested had not been able to provide satisfying results. Then, the farmer group spearheaded by Abdul Kurnaen learned to plant guava independently. They even went to West Java to get complete training and information.

Over time, almost 50 villages in Patean, Pageruyung, Plantungan, and Sukorejo have planted guava trees. By having so many guava trees, it will certainly lead to price fluctuations in the market. Even in the early years, the guava harvest boom caused low prices and many farmers cut down the trees and replant the rice as their main crop. Finally, this farmer group tried to collaborate with various parties including Kendal District and Central Java Provincial Government to expand the network and market.

At present, the number of farmers plus the workers has increased to 1,500 people. The land used is 2,000 hectares with a total of one million trees. On average, the guava farmers are able to produce approximately 2000 tons per month. By resulting in a very large number of guava crops, the JASMER Cluster is able to become the best agricultural cluster in Central Java in 2009-2010. The farmers then realize that when the number of the guava crop is abundant, the prices will be low and erratic. Now the farmers have also started to produce some products derived from guavas such as dodol, syrup, juice, jenang, jam, sweets, and etc. Kendal Regency and Central Java Provincial Government assist these farmers in several ways such as; processing assistance, training, tool assistance, business promotion, and permit and certification issuances.

\subsection{The Economic Empowerment Impact through the Livestock Village Program}

The researchers examined the impact of the Livestock Village program by looking at the development of farmers, the increase of the animals, the results during the maintenance process, and some other impacts enjoyed by the farmers. The following is an explanation of the impacts for each hamlet:

Table 1 Data from Nadawaziz Group

\begin{tabular}{|c|c|c|c|c|c|c|c|}
\hline No & Names & Year & First Goat & Goatling & Selling Goat & Total & THK \\
\hline 1. & $\begin{array}{l}\text { Nur } \\
\text { Rohmat }\end{array}$ & 2014 & 1 & 6 & 4 & 3 & 2 \\
\hline 2. & Robyong & 2014 & 1 & 7 & - & 8 & - \\
\hline 3. & Subandi & 2014 & 1 & 2 & 1 & 1 & 2 \\
\hline
\end{tabular}


4.

5. Sumarman

2014

2014

2014

6.

Wakini
1

1

1

5

6

$\begin{array}{lll}- & 1 & 4 \\ 3 & 3 & 2 \\ 6 & 1 & -\end{array}$

4

From the table above it can be obtained the information that the number of goats of each member was different due to several factors, one of which is sales. The higher the sales are, the higher the level of the dependence on the results of this program. Wakini is a farmer who often makes 6 goat sales. Her life is highly dependent on this program. Every time the broodstock gets a goatling, it grows bigger. Then it is sold by Wakini to fulfill her life needs.

Unlike Wakini, Robyong has never sold any of the goatlings of the brood stock from Dompet Dhuafa Yogyakarta. She wants to make her goats as savings. Robyong, a widow in fulfilling her life need, is not only dependent on the goatling of the Livestock Village program, but she still has an income from agricultural land.

Table 2. Data from Ngudi Rejeki Group

\begin{tabular}{|c|c|c|c|c|c|c|c|}
\hline No & Names & Year & First Goat & Goatling & Selling Goat & Total & THK \\
\hline 1. & Sugito & 2014 & 1 & 3 & - & 4 & 3 \\
\hline 2. & Sugiran & 2014 & 1 & 2 & - & 5 & 30 \\
\hline 3. & Sukarman & 2014 & 1 & 5 & 2 & 4 & - \\
\hline 4. & Priyo Utomo & 2014 & 1 & 7 & 5 & 3 & 6 \\
\hline 5. & Sukianto & 2014 & 1 & 6 & 2 & 5 & - \\
\hline 6. & Jarwo Kahono & 2014 & 1 & 4 & 2 & 3 & 3 \\
\hline
\end{tabular}

Presented the data in Gunungbutak Hamlet, the researchers can assess that the development in this hamlet is far more advanced than in Plengan Hamlet, Kulon Progo. This is evidenced by the numbers in the table above. The six people we chose as the informants began to join the Livestock Village program of Dompet Dhuafa Yogyakarta in 2014. They also got one broodstock for each household for the first twenty families. In term of the number of the goatling, Priyo Utomo becomes the largest with seven goats, followed by Sukianto with six goatlings, Sukarman with five goatlings, and the last one, Sugiran with two goatlings. Sukianto is one of the lucky brooders of Dompet Dhuafa Yogyakarta because the goatlings born from Dompet Dhuafa broodstock are always more than two, even it reached four goatlings in one delivery.

Broadly speaking, the benefits experienced by the members of the Livestock Village community of Dompet Dhuafa Yogyakarta are the increase of business results, the improvement of family living standard, and the increase of skills and knowledge.

\subsection{Inhibiting and Supporting Factors}

\subsubsection{Livestock Village of Dompet Dhuafa Yogyakarta}

The supporting factor of the program in Gunungbutak Hamlet becomes the inhibiting factor in Plengan Hamlet, except the breeding culture, in which the breeding culture is a supporting factor in the two hamlets 
and vice versa. The supporting factors in Gunungbutak Hamlet include: 1) The breeding culture, 2) Tenacious and persistent members, and 3) The close distance of the houses. While the supporting factors in Plengan Hamlet are: 1) Breeding culture, 2) Harmonious members, and 3) The availability of abundant animal feed.

The inhibiting factor in Gunungbutak Hamlet includes: 1) The difficulty to feed in the dry season. While the inhibiting factors in Plengan Hamlet are: 1) The lack of tenacious and persistent members, 2) The far distance of the houses.

\subsubsection{Kendal Red Getas Guava (JASMER)}

The constraints faced by the farmers in this community come from three factors, namely the management, marketing, and derivative product types. In management, on the average, they have their own activities in addition to being farmers so that they are less favorable in managing the community whose task is to assist the farmers for the training and the encouragement in cultivating guava. In marketing, the fresh guavas have not been able to penetrate their own markets, while currently these crops still widely depend on the brokers. The derivative product types are not too maximal due to the narrow market range and the unattractive packaging.

\section{Conclusions}

From the previous descriptions, it can be drawn some conclusions that the empowerment programs in both places have had a pretty good benefit for the breeders and the farmers. By the local wisdom approach, the breeding culture, rowdy system, and agricultural land suitability, the community can play an active role in the programs. The rowdy scheme in the Livestock Village program greatly benefits the members with a portion of 90:10. The mechanism of the selecting targets or the program locations by using very specific beneficiary criteria and the facilitator availability for the program assistance supports the sustainability of these programs. On the other hand, optimal land use supported by the individual's ability to cultivate one yield makes JASMER cluster also able to get better results than before.

As for some of the benefits of these programs, namely: 1) The increase of business income, 2) The improvement of family living standard, and 3) the increase of skills and knowledge.

\section{References}

1. Abidi, Z. (2012). Manifestasi dan Latensi Lembaga Filantropi Islam dalam Praktik Pemberdayaan Masyarakat (Suatu Studi di Rumah Zakat Kota Malang). Online: Jurnal Studi Masyarakat Islam (SALAM). Vol.15 No. 2. pp. 198

2. Darwan and Nur Iman, (2009). Meretas Arah Kebijakan Sosia Baru di Indonesia, Jakarta: Pustaka LP3ES, pp. 30

3. Gaduh. (2019) in KBBI Online. Retrieved from https://kbbi.web.id/gaduh

4. Sartika, M. (2008). Pengaruh Pendayagunaan Zakat Produktif terhadap Pemberdayaan Mustahiq pada LAZ Yayasan Solo Peduli Surakatra. Online: Jurnal La Riba. Vol. II, No.1. pp.77

5. Suharto, E. (2014). Membangun Masyarakat Memberdayakan Rakyat: Kajian strategis Pembangunan Kesejahteraan Sosial dan Pekerjaan Sosial. Bandung: Refika Aditama. E- Book. pp. 58

6. Wayan Edi, Ni Made Kariati, and Wayan Sukarta, (2016) "Pemberdayaan Masyarakat Berbasis Community Development (Studi Eksploratif Di Kawasan Wisata Sangeh)”, online Jurnal SOSHUM: Jurnal Sosial dan Humaniora vol. 6, No. 3, pdf, pp 241. 